\title{
ELEMENTS IN THE MARKET OF THE REAL ESTATE PROPERTY IN ORADEA
}

\author{
M.S. Mancia ${ }^{a}$, A. Mancia ${ }^{\text {a* }}$ \\ a University of Oradea, Faculty of Construction, Cadastre and Architecture, Department of Cadastre and Architecture, Oradea, \\ 4 B.St. Delavrancea Street, Romania \\ e-mails: *mancia.aurora@gmail.com, mancia.mircea@yahoo.com
}

Received: 27.05.2017 / Accepted: 20.08.2017 / Revised: 05.11.2017 / Available online: 15.12.2017

\section{DOI: 10.1515/jaes-2017-0012}

KEY WORDS: real estate market, economic and territorial administrative development, cross-border accessibility, supply and demand

\begin{abstract}
:
The location of Oradea in western Romania, in a constant development area, correlates with the existing human potential; the area becomes attractive for citizens from other geographic regions who have moved to Oradea. The real estate market of apartments is experiencing an increase reaching new highs in the trim. II 2017. The city of Oradea is part of the cities with economic potential, with the demand for housing. The prices upward trend must be corelated with economic growth and strength in order not to produce a new "crisis" effect.
\end{abstract}

\section{INTRODUCTION}

The administrative framework, by way of organization, hierarchy and geographical position, plays a key role in the management of real estate in different geographic areas.

The border area of the western region of Romania presents a specific typology: it correlates the human potential with the economic and social development. The main landmarks of an efficient real estate market are:

1. - cross-border accessibility,

2. - participation in the general framework for the implementation of the European Union's regional policies,

3. - easy access to the motorways in Hungary and Serbia,

4. - the political-administrative space strategically correlated with the human potential,

5. - territorial development with economic performances and economic, social and cultural objectives,

6. - efficient communication and transport systems,

7. - relational management between supply and demand of residential real estate,

8. - The area of polarization of different specific activities.

A recent World Bank study points out that around 3.6 million Romanians intend to move over the next five years; $66.5 \%$ would prefer to stay in the most attractive cities in Romania, currently being Bucharest, Cluj Napoca, Timisoara, Brasov.

From the real estate point of view Cluj reflects the best economic development of the west of the country: rents and apartment prices have sometimes surpassed the value of similar properties in Bucharest.

The value of the apartments in Cluj is approx. $78 \%$ higher than the lowest point reached in January 2014, respectively 818 euro/sqm useful area, and in September 2017, 1,455 euro / sqm net area. Cluj is the most powerful IT hub in Romania, wages are high and, as a result, residents can afford to offer more for apartments or rents.

Other cities, such as Oradea, Pitesti are in a continuous development and the real estate market is the mirror of local economic activities. They are on the map of interest markets in this domain.

\section{MATERIAL AND METHODS}

During the economic crisis, the purchase price of housing decreased by $2.4 \%-5.6 \%$ annually. The market was blocked, with a huge difference between the prices demanded by the owners and the actual transaction prices.

In 2013, Romania experienced the weakest residential market in the world with a decrease of $10.43 \%$ after a $5.9 \%$ decrease in $2012,6.99 \%$ in $2011,22.08 \%$ in 2010 and $24.22 \%$ in 2009 (global property guide.com).

*Corresponding author. Mancia Aurora, e-mail: mancia.aurora@gmail.com 
The residential property area has been greatly affected by the economic crisis: prices have decreased steadily, the number of transactions has been reduced, construction works have been blocked. The real estate market has become unstable and difficult to estimate as future developments.

In the years 2014 and 2015 , in the west of the country, there were developments with tendencies of stabilization in apartments; however, the land market for real estate developments and rents continued to fall slightly compared to price increases for apartments.

According to Eurostat, Romania was the only EU market where the national average house price dropped by $0.7 \%$ at the end of the year, compared with $+1.3 \%$ in the euro area and $+1.5 \%$ in EU (Table 1).

Table 1. Percentage increases in house prices in the EU States

\begin{tabular}{|l|c|c|}
\hline & Sem. I, 2016 & Sem. II, 2016 \\
\hline Average in UE & 1,3 & 1,5 \\
\hline UK & 2,9 & 1,9 \\
\hline Finland & 0,9 & 0,00 \\
\hline Romania & 2,8 & $-0,7$ \\
\hline Poland & 0,8 & 1,9 \\
\hline Austria & 2,3 & 0,5 \\
\hline Hungary & 1,4 & 3,4 \\
\hline France & 0,5 & 2,5 \\
\hline Spain & 1,8 & 0,8 \\
\hline Germany & 2,9 & 1,2 \\
\hline Bulgaria & 2,8 & 1,6 \\
\hline Italy & 0,3 & 0,1 \\
\hline
\end{tabular}

According to the National Institute of Statistics, in 2015, the real estate market in Romania is growing.

The year 2017 brought the elimination of the tax for real estate transactions of up to 450,000 lei; those exceeding this amount are taxed by $3 \%$ for the difference between the value of the property transaction and the threshold of 450,000 lei (O.U.G. on the amendment of Article 111 of the Fiscal Code 2017).

The increase in consumption, wages, banks' flexibility for providing bonuses led to an average increase of $8.8 \%$ (real estate.ro, 26.05.2017).

The residential market in Romania is growing rapidly in 2017, an unprecedented increase that may be risky (Financial Stability Report, issued by the NBR in May 2017). There are regular, not speculative transactions. A reason for the price increases is also given by the fewer offers on the market than previous years and the more demanding housing demand.

There are some trends in the real estate market:

- increasing interest in quality. People who purchase dwellings are studying the quality of the building, building materials, and demanding the opinion of some purchasing specialists;

- $\quad$ integrated lifestyle, with quick access to facilities that simplify their lives: schools, green spaces, shopping areas, car parks, means of transport, safety;

- changing old dwellings with new ones for modern conditions, at modest prices;
- accessing the First House program that is still in force;

- $\quad$ acquisition for reinvestment of capital around a rate of approx. $10 \%$ of buyers (New Residence developer statistics).

Oradea is part of the localities that are becoming more interesting from an economic, tourist and architectural point of view. The location at $10 \mathrm{~km}$ from the border with Hungary, fast access to Central and Western Europe is an asset for the economic, cultural and tourist development of the area.

The modernization of Oradea International Airport is of strategic importance; a high potential for passenger and freight transport with direct external links across Europe has been created.

The revitalization of the historical center and the construction of modern leisure areas and Baile Felix and Oradea also led to an increase in the number of hotel rooms.

Development of Industrial Parks in Oradea, the arrival of foreign firms in the city led to the upward trend in the local real estate market (Figure 2).

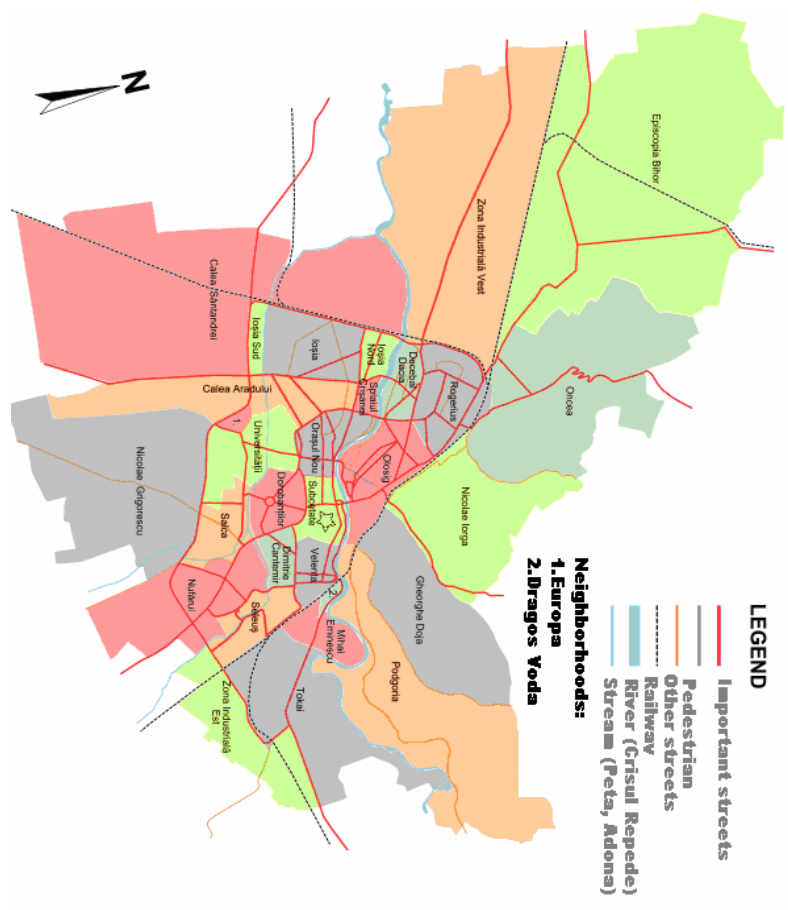

Figure 2. Oradea map on neighborhoods

The current average price of the living quarters is approx. $30.5 \%$ over the lowest value at the beginning of the crisis.

In 2013, average prices per built square meter were still decreasing compared to the start of the crisis (Table 3, Figure 4). 
Table 3. Values per square meter of housing in Oradea

\begin{tabular}{|l|c|}
\hline \multicolumn{1}{|c|}{ Year } & Price in euro sqm \\
\hline 2013 & 836 \\
\hline 2014 & 823 \\
\hline 2015 & 699 \\
\hline 2016 & 722 \\
\hline 2017, trim. I & 794 \\
\hline
\end{tabular}

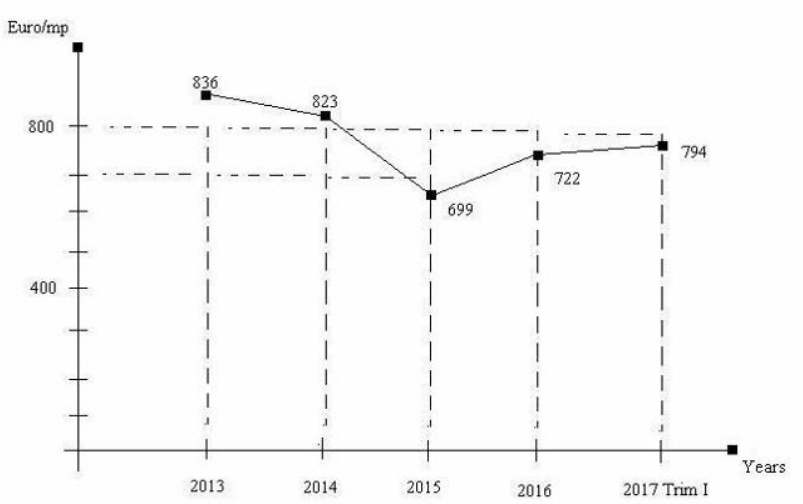

Figure 4. Values per sqm for housing in Oradea (Study Dorian, DRS)

The price of old flats located in the central area is rising due to the labor force crisis in construction has led to higher house prices; building materials, new technologies have led to rising real estate prices, integrated lifestyle with fast access to commercial facilities, schools, parking, culture, health.

The most demanded and the most sought are the two-room apartments with prices between 40-53.000 euro, representing approx. $53 \%$ of the market.

In the 1 st and 2 nd semestre of 2017 , the price increase for 2 room apartments was $10 \%$ on average. On the neighbourhoods, the prices of the 2-room apartments had average values (Table 5).

Table 5. Average values of 2 room-flats

\begin{tabular}{|c|c|c|c|c|}
\hline Year & $\begin{array}{c}\text { Central } \\
\text { area } \\
\text {-euro- }\end{array}$ & $\begin{array}{c}\text { Rogerius } \\
\text {-euro- }\end{array}$ & $\begin{array}{c}\text { Ioşia } \\
\text {-euro- }\end{array}$ & $\begin{array}{c}\text { Velenţa } \\
\text {-euro- }\end{array}$ \\
\hline 2013 & $\begin{array}{c}27.000- \\
46.000\end{array}$ & $30-40.000$ & $20-30.000$ & $20-32.000$ \\
\hline 2015 & $\begin{array}{c}35.000- \\
60.000\end{array}$ & $30-45.000$ & $25-40.000$ & $20-30.000$ \\
\hline 2017 & $57.000-$ & $33-50.000$ & $35-45.000$ & $23-45.000$ \\
& 75.000 & & & \\
\hline
\end{tabular}

These are average values because, depending on the location, facilities, access, floor, finishes, apartments were sold and with lower or higher values.

The data published by the National Institute of Statistics and Bihor County Department of Statistics are presented in Table 6 and Figure 7.
Table 6. Housing completed between 2013-2017, sem. I (Monthly Statistical Bulletin of Bihor County)

\begin{tabular}{|l|c|c|c|c|c|}
\hline & 2013 & 2014 & 2015 & 2016 & $\begin{array}{c}2017, \\
\text { sem. I }\end{array}$ \\
\hline urban & 363 & 489 & 379 & 567 & 408 \\
\hline rural & 475 & 543 & 517 & 573 & 190 \\
\hline Total & 838 & 1.032 & 896 & 1.140 & 598 \\
\hline
\end{tabular}

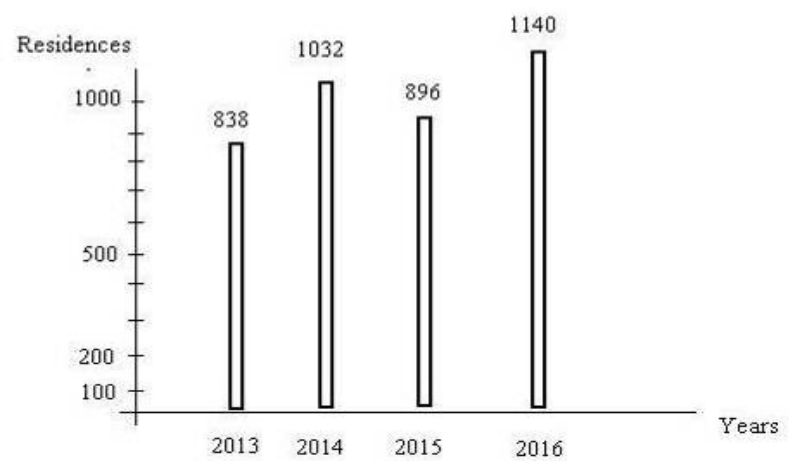

Figure 7. Housing completed between 2013-2016

It was been noted that in 2014, $18.79 \%$ more homes were completed than in 2013. In 2015 the number of completed dwellings was $-11.5 \%$ less than in 2014 . The year 2016 led to an increase of $+21.4 \%$ compared to 2015 . In the first semester of this year 598 homes were completed compared to 2017 at the end of the sem. I 2016. I 2017 is $+36.28 \%$.

As you can see, Oradea falls within the estimated general rate of annual growth of $18.79 \%, 21.4 \%$ and $36.2 \%$. The exception is 2015 , the year in which the trend has been decreasing.

\section{CONCLUSION}

At the "Real Estate \& Construction Form" conference at the end of oct. 2017, was analyzed the country risk management of the Romanian real estate market on different sectors:

- A growing factor of the demand in this market represents the economic development: Brexit and the uncertain situation in some EU countries can bring the relocation of some companies to Romania, as well as the repatriation of some Romanians who want to do business in the country.

- The real estate market is more consolidated, grown up, and the rise in property prices is not aggressive as it was in 2007.

Oradea is a dynamic city with potential and demand from the point of the real estate market. Gradually, there was normalization of this market with relatively constant price increase.

There is interest in housing quality. There are new projects built by established developers as well as private investors.

Government funding programs for real estate remain among the favorite of those who want to buy. 


\section{REFERENCES}

Ilieş Al., 2007. Romanian territories included în cross-border cooperation regions, in Romania Atlas Istorico-Geografic, Ed. Academiei Române, Bucureşti.

Ianoș I., Heller W., 2006. Spaţiu economic şi sistem de aşezări (Economic space and settlements system), Ed. Tehnică, Bucureşti.

Mancia M.S., 2015. Geopolitică şi planificare teritorială în bazinul hidrografic al Crişurilor Repede (Geopolitics and territorial planning in the hydrographic basin of Crişul Repede), Ed. Universităţii din Oradea.

Raport asupra stabilităţii financiare a României (Report on Romania's Financial Stability), May 2017.

O.U.G. nr. 3 din 6.ian. 2017 pentru modificarea şi completarea Legii nr. 227/2015 privind Codul fiscal (O.U.G. no. 3 of 6.ian. 2017 for amending and completing the Law no. 227/2015 regarding the Fiscal Code).

Codul fiscal, 2017, art. 111 (Fiscal Code).

Eurostat - Preţul locuinţelor în UE, 2016 (House prices in the EU).

Institutul Naţional de Statistică 2014, 2015, 2016 - preţul locuintelor (National Institute of Statistics 2014, 2015, 2016 housing prices).

Direcţia Județeană de Statistică Bihor. Buletin statistic lunar nr. 10/2014; nr. 10/2015; nr. 10/2016 (Bihor County Statistical Office. Monthly Statistical Bulletin no. 10/2014; no. 10/2015; no. $10 / 2016$ ).

www.capital.ro: Alex Urzică - Criza forţei de muncă scumpeşte proprietăţile (The labor crisis makes properties expensive), viewed at 20.09.2017.

www.ziarulfinanciar.ro: Alina Elena Vasiliu - Index imobiliar (Real estate index), viewed at 04.07.2017.

www.adevarul.ro.economie: Elena Deacu - Şapte tendinţe pe piaţa imobiliară (Seven Trends in the Real Estate Market), viewed at 06.06.2017.

www.startups.ro/analize/in-2017/, viewed at 30.oct.2017.

www.capital.ro, viewed at 01.02.2017.

www.imobiliare.ro, viewed at 26.05.2017.

www.globalpropertyguide.com.
Ziarul Financiar (the Financial Newspaper), 15.06.2017, Bogdan Alecu. 